\title{
MENINGKATKAN MOTIVASI BELAJAR BAHASA INDONESIA DENGAN MENGGUNAKAN MODEL PEMBELAJARAN KOOPERATIF TIPE TGT (TEAMS GAMES TOURNAMENT) PADA SISWA KELAS IV SD NEGERI 106815
}

\author{
Wesly Silalahi \\ Surel: weslysilalahi@yahoo.com
}

\begin{abstract}
ABSTRAK
Penelitian ini bertujuan untuk memudahkan siswa dalam memahami dan menguasai materi pelajaran sehingga siswa terlibat langsung dalam proses pembelajaran yang berbentuk permainan berkelompok yang berupa pertanyaanpertanyaan yang berkaitan dengan materi pelajaran Bahasa Indonesia. Penelitian ini dilaksanakan di SD Negeri 106815 Patumbak. Jenis penelitian ini adalah penelitian tindakan kelas (PTK) dengan menggunakan model pembelajaran Kooperatif tipe TGT (Teams Games Tournament). Dari hasil penelitian yang telah dilakukan oleh peneliti, dapat diketahui rata-rata motivasi belajar siswa secara individu pada setiap siklus terjadi peningkatan secara signifikan. Siswa yang termotivasi pada siklus I pertemuan 1 sebesar 7\%, pada siklus I pertemuan 2 sebesar 11\%, pada siklus II Pertemuan 1 sebesar $68 \%$ dan siswa yang termotivasi pada siklus II pertemuan 2 sebesar 79\%. Berdasarkan hasil penelitian, maka dapat disimpulkan bahwa model pembelajaran Kooperatif tipe TGT (Teams Games Tournament) dapat meningkatkan motivasi belajar siswa kelas IV SD Negeri 106815 pada mata pelajaran Bahasa Indonesia.
\end{abstract}

Kata Kunci: Model Pembelajaran, Teams Games Tournament, Motivasi Belajar

\section{PENDAHULUAN}

Belajar Bahasa Indonesia pada hakikatnya adalah belajar komunikasi. Pendidikan Bahasa Indonesia merupakan salah satu aspek penting yang perlu diajarkan kepada para siswa di sekolah. Mata pelajaran Bahasa Indonesia diberikan sejak bangku sekolah dasar karena diharapkan siswa mampu menguasai, memahami dan dapat mengimplementasikan keterampilan berbahasa seperti membaca, menyimak, menulis dan berbicara.
Pembelajaran bahasa diharapkan membantu siswa mengenal dirinya, budayanya, dan budaya orang lain, mengemukakan gagasan dan perasaan, berpartisipasi dalam masyarakat yang menggunakan bahasa tersebut dan menemukan serta menggunakan kemampuan analitis dan imaginatif yang ada dalam

Dalam kegiatan belajar, motivasi dapat dikatakan sebagai keseluruhan daya penggerak di dalam diri siswa yang menimbulkan,

Program Studi PGSD Universitas Negeri Medan 
menjamin kelangsungan dan memberikan arah kegiatan belajar, sehingga diharapkan tujuan tercapai.

Pemilihan model pembelajaran yang tepat maka akan mempengaruhi belajar siswa dengan baik sehingga siswa benar-benar memahami materi yang diberikan kepada mereka. Adapun penggunaan suatu model pembelajaran hendaknya dapat menempatkan anak didik pada keterlibatan aktif belajar, mampu menumbuhkan dan mengembangkan perolehan hasil belajar serta menghidupkan proses pengajaran yang sedang berlangsung.

Untuk itu diperlukan suatu upaya dalam rangka meningkatkan mutu pendidikan dan pengajaran salah satunya adalah dengan memilih strategi atau cara dalam penyampaian materi pelajaran agar diperoleh peningkatan hasil belajar siswa khususnya pelajaran Bahasa Indonesia. Misalnya dengan membimbing siswa untuk bersama sama terlibat aktif dalam proses pembelajaran dan mampu membantu siswa berkembang sesuai dengan taraf intelektualnya akan lebih menguatkan pemahaman siswa terhadap konsep konsep yang diajarkan. Pemahaman ini memerlukan minat dan motivasi.

Maka guru harus memberikan dorongan dalam bentuk motivasi sehingga dengan dorongan itu peserta didik dapat keluar dari kesulitan belajar. Berdasarkan pengalaman peneliti di lapangan, kegagalan dalam belajar rata-rata dihadapi oleh sejumlah siswa yang memiliki dorongan belajar.

Dari observasi yang dilakukan peneliti di sekolah SD Negeri 106815 Patumbak Pada mata pelajaran Bahasa Indonesia masih banyak yang belum mencapai KKM 7.0. Maka peneliti akan mengulang pelajaran dengan materi mendengarkan pengumuman. Hal ini disebabkan karena guru dalam proses belajar mengajar hanya mengunakan metode ceramah, tanpa mengguna-kan alat peraga dan materi pelajaran tidak disampaikan secara kronologis. Kurangnya motivasi belajar siswa membuat hasil belajar siswa menjadi rendah. Pada materi pengumuman siswa kurang jelas terhadap penjelasan yang terdapat di buku pelajaran membuat siswa susah untuk memahami materi pengumuman. Hal itu disebabkan karena guru kurang tepat dalam menetapkan model pembelajaran yang sesuai dengan matei pembelajaran.

Salah satu upaya peneliti yang akan diterapkan di SD Negeri 106815 Patumbak, untuk meningkat -kan motivasi belajar siswa pada mata pelajaran Bahasa Indonesia adalah dengan menerapkan model pembelajaran kooperatif tipe Teams Games Tournament. Model pembelajaran kooperatif tipe Teams Games Tournament memberi 
kesempatan kepada siswa untuk berfikir, menjawab dan saling membantu satu sama lain. Variasi model pembelajaran ini lebih menarik, menyenangkan, dan dapat meningkatkan motivasi belajar siswa.

Model pembelajaran Teams

Games Tournament adalah salah satu tipe atau model pembelajaran kooperatif yang mudah diterapkan, melibatkan aktivitas seluruh siswa tanpa harus ada perbedaan status, melibatkan peran aktivitas belajar dengan permainan yang dirancang dalam siswa sebagai tutor sebaya dan mengandung unsur permainan dan penguatan.

Berdasarkan uraian di atas, maka penulis tertarik untuk mengadakan penelitian dengan judul: "Meningkatkan Motivasi Belajar Bahasa Indonesia Dengan Menggunakan Model Pembelajaran Kooperatif Tipe TGT (Teams Games Tournament) Pada Siswa Kelas IV SD Negeri 106815 Tahun Ajaran 2015/2016."

Berdasarkan latar belakang masalah maka dapat diidentifikasikan masalah-masalah yang terjadi sebagai berikut:

1. Kurangnya motivasi belajar siswa pada mata pelajaran Bahasa Indonesia disebabkan oleh model pembelajaran yang digunakan guru masih bersifat konvensional sehingga hasil belajar siswa rendah.
2. Guru kurang tepat dalam menggunakan model pembelajaran pada materi yang diajarkan disebabkan oleh Rendahnya hasil belajar siswa pada mata pelajaran Bahasa Indonesia.

Adapun tujuan penelitian ini adalah untuk meningkatkan motivasi belajar siswa dengan menggunakan pembelajaran kooperatif tipe TGT (Teams Games Tournament) pada mata pelajaran Bahasa Indonesia Pada Materi pokok Mendengarkan Pengumuman di Kelas IV SD Negeri 106815 Patumbak Tahun ajaran 2015/2016.

Manfaat penelitian ini adalah:

1. Bagi siswa, melalui penggunaan model pembelajaran kooperatif tipe TGT (Teams Games Tournament) dapat meningkatkan motivasi belajar siswa pada mata pelajaran Bahasa Indonesia

2. Bagi guru, sebagai bahan masukan kepada guru untuk menerapkan model pembelajaran kooperatif tipe TGT (Teams Games Tournament) di SD Negeri 106815 Patumbak Tahun ajaran 2015/2016.

3. Bagi sekolah, sebagai bahan masukan bagi sekolah dalam meningkatkan motivasi belajar siswa.

4. Bagi peneliti, sebagai bahan masukan bagi peneliti untuk 
diterapkan pada proses belajar mengajar nantinya.

5. Bagi peneliti lanjut, sebagai bahan masukan dalam penelitian berikut jika ingin meneliti dengan penelitian yang sejenis.

\section{METODE PENELITIAN}

Jenis penelitian ini adalah Penelitian Tindakan Kelas (Classroom Action Research), yaitu sebuah kegiatan penelitian yang dilakukan di kelas. Penelitian ini bertujuan untuk memperbaiki proses pembelajaran dalam meningkatkan motivasi belajar siswa melalui model pembelajaran Kooperatif tipe Team Games Tournament.

Penelitian ini dilaksanakan di SD Negeri 106815 Marindal 1 Kecamatan Patumbak, Kabupaten Deli Serdang Tahun Ajaran 2015/ 2016 pada semester genap. Waktu penelitian dari bulan Januari-Maret 2016.

Subjek dalam penelitian tindakan kelas ini adalah siswa/i kelas IV SD Negeri 106815 Patumbak Kabupaten Deli Serdang Tahun Ajaran 2015/2016. yang berjumlah 28 orang siswa, yang terdiri dari 5 lakilaki dan 23 Perempuan. Objek dalam penelitian ini adalah penggunaan model pembelajaran Teams Games Tournament untuk meningkatkan motivasi belajar siswa.

Alat yang digunakan dalam pengumpulan data penelitian ini adalah berupa instrumen untuk mencatat semua aktivitas sis selama tindakan berlangsung. Alat pengumpulan data yaitu:

1. Lembaran Observasi

2. Angket

Tingkat keberhasilan belajar siswa dapat digunakan dengan menggunakan rumus:

$$
P=\frac{F}{N} \times 100
$$

Keterangan :

$\mathrm{P}=$ Nilai yang diperoleh

$\mathrm{F}=$ Skor yang diperoleh siswa

$\mathrm{N}=$ Skor maksimum

Maka nilai siswa yang termotivasi pada mata pelajaran Bahasa Indonesia dengan menggunakan model pembelajar TGT harus mencapai nilai $>75$. Untuk mengetahui nilai ketuntasan belajar siswa digunakan rumus:

$$
P K K=\frac{F}{N} \times 100 \%
$$

Keterangan :

PKK = Prestasi Komulatif Kelas

$\mathrm{F} \quad=$ Siswa Yang Termotivasi

$\mathrm{N}=$ Jumlah Siswa

\section{HASIL DAN PEMBAHASAN}

Penelitian ini dilakukan di SD Negeri 106815 Patumbak pada kelas IV A semester genap pada tahun 2015/2016 yang berjumlah 28 orang siswa yang terdiri dari 5 laki laki dan 
23 perempuan. Selama penelitian berlangsung kehadiran siswa diupayakan $100 \%$ agar tidak mempengaruhi kesimpulan hasil penelitian.

Dalam Penelitian Tindakan Kelas ( PTK) ini yang dilakukan adalah mengidentifikasi masalah yang akan diteliti. Dalam pelaksanaan penelitian ini, kegiatan yang dilakukan peneliti terlebih dahulu adalah dengan memberi angket pada siswa kelas IV SD Negeri 106815 Patumbak dengan tujuan untuk mengetahui motivasi belajar siswa pada mata pelajaran Bahasa Indonesia materi Mendengarkan Pengumuman.

Hasil penelitian yang

dilakukan di SD Negeri 106815 Patumbak menunjukkan bahwa penerapan model pembelajaran Kooperatif tipe TGT ( Teams Games Tournament) dapat meningkatkan motivasi belajar siswa pada materi Mendengarkan Pengumuman di kelas IV SD. Hasil penelitian ini dapat dilihat dari hasil angket, observasi motivasi belajar siswa dan observasi guru.

Berdasarkan dari hasil penyebaran angket, dapat dilihat bahwa terdapat suatu peningkatan dan perubahan secara signifikan terhadap motivasi belajar siswa dengan menggunakan model pembelajaran Teams Games Tournament.
1. Hasil angket motivasi belajar siswa.

Dari hasil angket motivasi belajar siswa pada saat sebelum pembelajaran diperoleh data dari 28 orang siswa secara keseluruhan siswa belum termotivasi dalam mengikuti pelajaran Bahasa Indonesia. Hal ini terlihat siswa yang termotivasi ada 6 orang dan siswa yang belum termotivasi ada 22 orang siswa. Berdasarkan hasil penelitian ini, dapat dikatakan bahwa hasil angket motivasi belajar siswa pada kondisi awal yang dilakukan peneliti menunjukkan bahwa tingkat motivasi belajar pada materi mendengarkan pengumuman tergolong rendah. Beberapa kesulitan yang dihadapi yaitu siswa menganggap remeh pada pelajaran Bahasa Indonesia. Oleh karena itu data hasil penelitian ini dapat dijadikan acuan untuk melakukan tindakan dengan menggunakan model pembelajaran kooperatif tipe TGT ( Teams Games Tournament).

Upaya yang dilakukan peneliti untuk mengatasi kesulitan tersebut yaitu dengan memperbaiki proses belajar mengajar agar tingkat motivasi belajar siswa meningkat dan mencapai tingkat keberhasilan. Pada siklus II ini, peneliti mengoptimalkan siswa secara sungguh-sungguh pelaksanaan model pembelajaran kooperatif tipe TGT (Teams Games Tournament). Hal ini bertujuan untuk 
mengaktifkan siswa dalam proses pembelajaran.

Pada siklus II diperoleh data dari 28 orang siswa, siswa yang termotivasi ada 27 orang dan siswa yang belum termotivasi hanya 1 orang siswa. Dengan adanya peningkatan tersebut maka peneliti tidak perlu lagi untuk melanjutkan penelitian selanjutnya.

Rekap hasil keseluruhan angket motivasi belajar siswa dapat dilihat pada grafik seperti berikut:

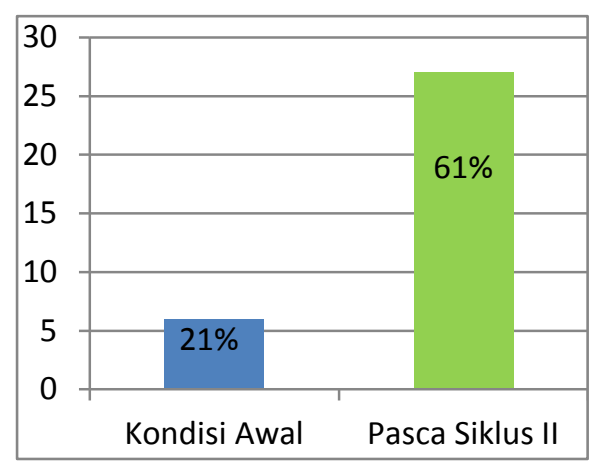

\section{Diagram 4.4 Persentase Jumlah Ketuntasan Hasil Angket Dari Kondisi Awal Sampai Pasca Siklus II}

2. Hasil observasi tingkat motivasi belajar siswa.

Berdasarkan hasil penelitian dari kondisi awal ke siklus I dan siklus II yang dilakukan oleh peneliti telah terjadi peningkatan motivasi belajar siswa. Hal ini dapat terlihat pada diagram persentase tingkat motivasi belajar siswa dari siklus I pertemuan 1 sampai siklus II pertemuan 2 di bawah ini.

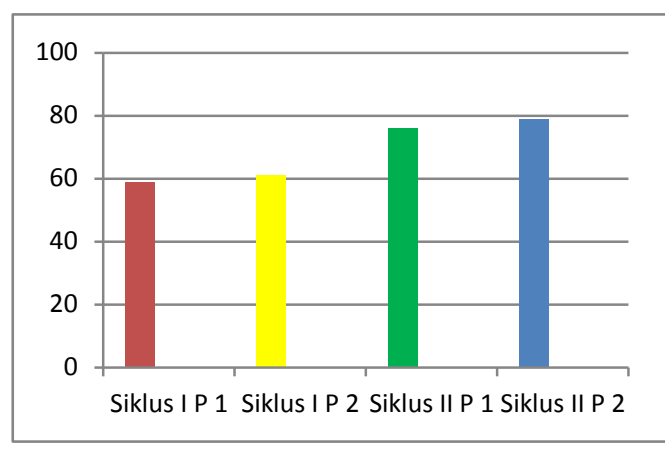

Diagram 4.5. Rekap Persentase Peningkatan Motivasi Belajar Dari Kondisi Awal Sampai Siklus II Menggunakan Model TGT

\section{SIMPULAN}

Berdasarkan hasil dan pembahasan penelitian yang telah dilakukan pada Pelajaran Bahasa Indonesia dengan menggunakan model Pembelajaran TGT (Teams Games Tournament) dapat ditarik kesimpulan sebagai berikut:

1. Motivasi belajar siswa kelas IV SD Negeri 106815 pada materi pokok mendengarkan pengumuman dengan mengguna kan model pembelajaran TGT telah mengalami perubahan dan peningkatan dibandingkan sebelum dilakukannya model pembelajaran ini.

2. Dengan menggunakan model pembelajaran TGT telah memberikan semangat baru kepada siswa untuk mampu bersaing sehat, mampu menerima kekalahan dan dapat barbaur kepada semua teman. 
3. Dari hasil penelitian yang telah dilakukan oleh peneliti, dapat diketahui dari rata-rata motivasi belajar siswa secara individu pada setiap siklus terjadi peningkatan secara signifikan. Siswa yang termotivasi pada siklus I pertemuan 1 sebesar 7\%, siswa yang termotivasi siklus I pertemuan 2 sebesar $11 \%$, siswa yang termotivasi pada siklus II pertemuan 1 sebesar $68 \%$ dan siswa yang termotivasi siklus II pertemuan 2 Sebesar 79\%. Pada penyebaran angket kondisi awal sebesar $21 \%$ dan pada siklus II sebesar $96 \%$.

Saran yang dapat disampaikan pada penelitian ini adalah:

1. Kepada guru kelas IV SD Negeri 106815 agar dapat menerapkan Model Pembelajaran Kooperatif tipe TGT pada pembelajaran, karena dengan menggunakan model pembelajaran TGT dapat meningkatkan motivasi belajar siswa, pembelajaran menjadi lebih menarik, siswa diharapkan mampu bekerja sama pada kelompok.

2. Pada pelaksanaan Model Pembelajaran Kooperatif Tipe TGT ini akan menjadikan siswa lebih bertanggung jawab, karena seluruh siswa berperan penting dalam penilaian akhir pada games yang diberikan.
3. Kepada siswa untuk lebih banyak membiasakan mengerjakan latihan-latihan dirumah agar untuk meningkatkan rasa percaya diri dalam menjawab pertanyaanpertanyaan yang diberikan guru.

4. Kepada siswa untuk terus berusaha memotivasi diri sendiri dalam mengikuti pelajaran Bahasa Indonesia agar ilmu yang dipelajari dapat dimengerti dan menjadi suatu bekal yang sangat berguna pada masa yang akan datang.

\section{DAFTAR RUJUKAN}

Aqib, Zainal dkk. 2009. Penelitian Tindakan Kelas. Bandung: Yrama Widya.

Dewi, $\quad 2010$. Profesionalisme Guru Melalui Penelitian Tindakan Kelas. Pasca Sarjana Unimed.

Eveline, dkk. 2014. Teori Belajar dan Pembelajaran. Bogor: Ghalia Indonesia.

Hamdani. 2011. Strategi Belajar Mengajar. Bandung: Pustaka Setia.

Isjoni. 2011. Cooperative Learning. Bandung: Alfabeta.

Iskandar. 2009. Psikologi Pendidikan. Cetakan pertama. Jakarta: GP press. 
Purwanto. 2011. Evaluasi Hasil Belajar. Yogyakarta: Pustaka Belajar.

Sardiman AM. 2014. Interaksi dan Motivasi Belajar Mengajar. Jakarta: Rajawali Pers.

Shoimin, Aris. 2014. 68 Model Pembelajaran Inovatif dalam Kurikulum 2013. Yogyakarta: AR-Ruzz Media

Slameto. 2013. Belajar \& FaktorFaktor yang Mempengaruhinya. Jakarta: PT. Rineka Cipta.

Sri Wintala Achamd. 2015. Bahasa dan Sastra Indonesia. Yogyakarta: Araska.

Sumardi. 2000. Buku Pelajaran Bahasa Indonesia SD. Jakarta: PT. Grasindo.

Sumiati, dkk. 2013. Metode Pembelajaran. Bandung: Wacana Prima.

Suprijono, Agus .2009. Cooperative Learning. Yogyakarta: Pustaka Belajar.

Trianto. 2009. Mendesain Model Pembelajaran InovatifProgresif. Jakarta: Kencana. 